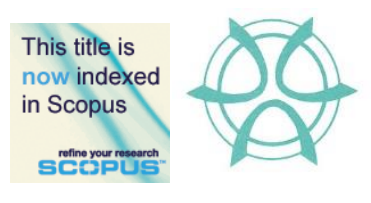

PLANNING MALAYSIA:

Journal of the Malaysian Institute of Planners

VOLUME 16 ISSUE 1 (2018), Page 205 - 210

\title{
INHERITING THE CITY: HISTORIC URBAN LANDSCAPE OF GEORGE TOWN UNESCO WORLD HERITAGE SITE
}

\author{
Rohayah Che Amat ${ }^{1}$ \\ ${ }^{1}$ UTM Razak School of Engineering and Advanced Technology \\ UNIVERSITI TEKNOLOGI MALAYSIA
}

\begin{abstract}
This research presents the value of historic urban landscape (HUL) elements in influencing the character of George Town UNESCO World Heritage Site (WHS), Penang, Malaysia. The values were perceived by the local community of different social-cultural groups that occupied the study area. The historic urban landscape elements constitute towards the protection of its townscape. The identification of the heritage elements influenced by the community interaction with their environment. This study also helps to define the character of a place, as well as reflecting its historical significance. The study adopted four techniques to gather both qualitative and quantitative data, including questionnaire survey, in-depth interview, visual survey and content analysis. In general, the local community has the capability in valuing the historic urban landscape values. The outcomes of their perceptions became the statement of the historic urban landscape values, which are expected to lead to the development of the areas. The community evaluation and perception can be expanded in implementing any development of the historic urban area by the authority.
\end{abstract}

Keyword: historic urban landscape, character, UNESCO World Heritage Site. 
Rohayah Che Amat

Inheriting the City: Historic Urban Landscape of George Town Unesco World Heritage Site

\section{INTRODUCTION}

George Town and Melaka were inscribed as UNESCO World Heritage Site on 7th July 2008. These sites known as the "Historic Cities of the Straits of Malacca". George Town is the capital city of Penang. This city was the first British port town and the oldest British colonial town in South East Asia. It represents 18th century of British footprint development and different from other places in the East and Southeast Asia (UNESCO, 2008). George Town represents 200 years of multi-cultural trading exchange between the West and the East, in which have created a tangible and intangible heritage. These elements convey a multi-cultural identity to the city. The heritage values of George Town lies on the Outstanding Universal Values (OUV) inscribed by UNESCO. The values of its contemporary uses and functions need to be taken into account during the evaluation.

Historic urban landscape (HUL) approach defines four variables to be implemented on the heritage management, which are: attributes, values, stakeholders and strategies (UNESCO, 2011; Bandarin \& Van Oers, 2012; 2015; Veldpaus, 2013). This research presented the attributes and values of HUL. Theoretically, the historic urban landscape values could unite the level of local practices by the inclusion of the individual (through his/her perception) and the community (through its value and genius loci). The community are the best sources of data in presenting the landscape issue and its values. They play an important role in illustrating the values and their associations. The visual aesthetic is the process and output of individual's perception towards the landscape. The heritage values of inheriting city are related to the notion of authenticity and integrity of the place. The values has a relation with the meaning and quality of the site, object or place (Jokiletho, 2007; 2006; 2005; 2002). The people's perception created the concept of landscape. In maintaining the heritage city, the policy makers need to consider community's perception in valuing these HUL elements. The heritage is the survival item that portrays the meaning and identity of the place. The significant value of the HUL provides lasting personal value as memories which capture and evoke the past event or nostalgia.

\section{THE INHERITING VALUES OF GEORGE TOWN UNESCO WORLD HERITAGE SITE}

The paper identifies four categories of values through study area, which are evidential, historical, communal and aesthetic. The character of this inheriting city was organized and remembered by selection of significant historic urban landscape (HUL) elements. There are four (4) factors that represent the historic values of George Town, which are: Historic character and identity; landscape and open space; heritage and townscape; and the meaning attached. The HUL elements that represent these four factors are: (i) landmark, edges, path/street, district and nodes; (ii) the parks and open space, the tree and street furniture; (iii) 
architecture and buildings; the visual and scenery (the setting); (iv) functional and emotional meaning.

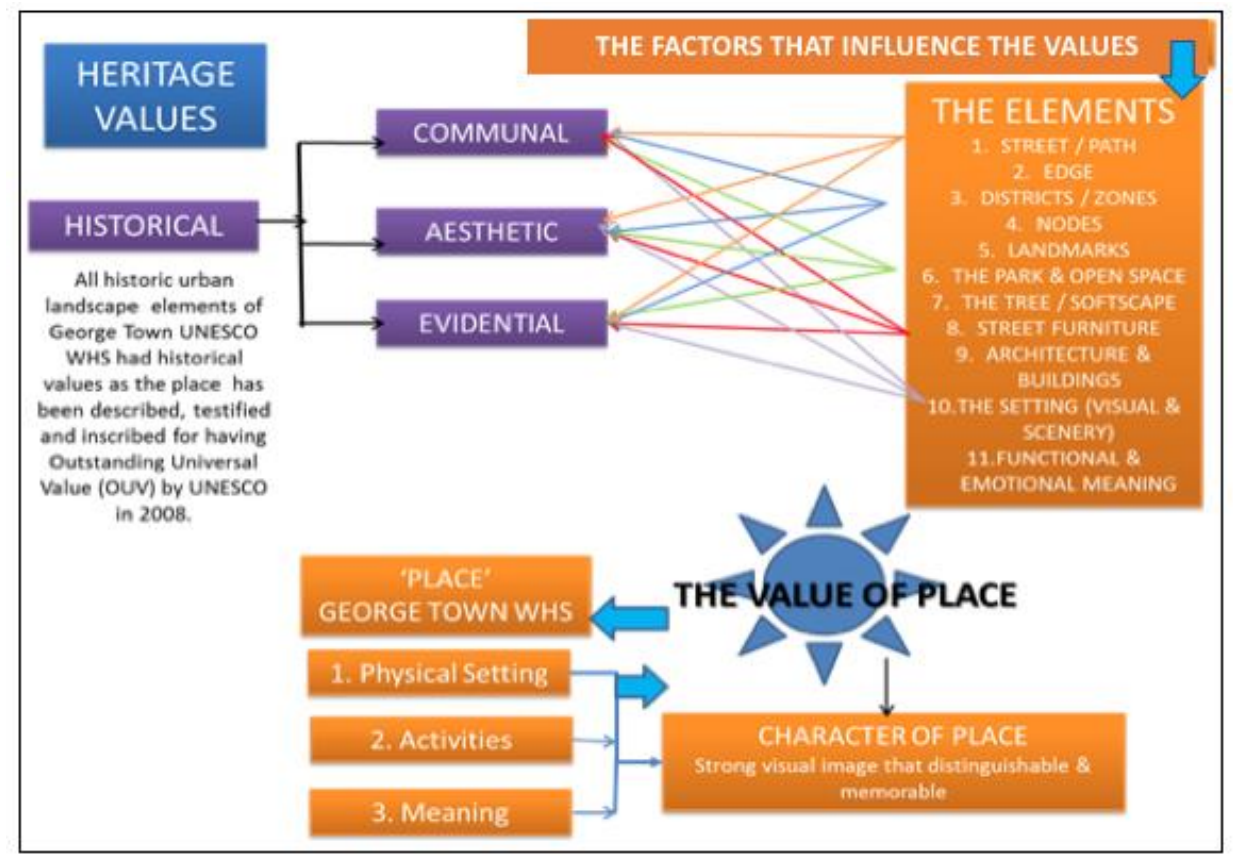

Figure 1: The value mapping of George Town UNESCO World Heritage Site Source: Author, 2018

The values are the result of an interrelation between four factors (Figure 1) that influence the character of George Town. In the findings, the four values outlined are overlapping between each other. The landmarks such as a historical clock tower, religious buildings or historical setting are related to its historical value. These historical worshiping places and heritage buildings or institutions play a role in the development of the community. They also had aesthetic value, in which the architectural and design of the buildings and their setting embrace the form and qualities of aesthetic dimensions. Furthermore, the values overlapping with communal value that give the meaning and association towards the community. The historical development of George Town was portrayed by its evidential value of 200 years of historical existence.

\section{Meaning of Inheriting City by Local Community}

The meaning of the place is associated with the locals. They described it as the memories and experiences towards George Town. These experiences contribute to the place meaning and association. The locals described the emotions or feelings towards the place and how much it meant to them. The interpretation on 
Rohayah Che Amat

Inheriting the City: Historic Urban Landscape of George Town Unesco World Heritage Site

how people value the historic urban landscape suggests that the history and its cultural context based on personal and collective memories of the individual. The finding suggests (Figure 2) that personal history of the individuals are indicated through the memory of the historical events. It indicates communal and historical value of the George Town. These two values collaborate with the surrounding environments of the past and the present in which carries the aesthetic and evidential values of the city.

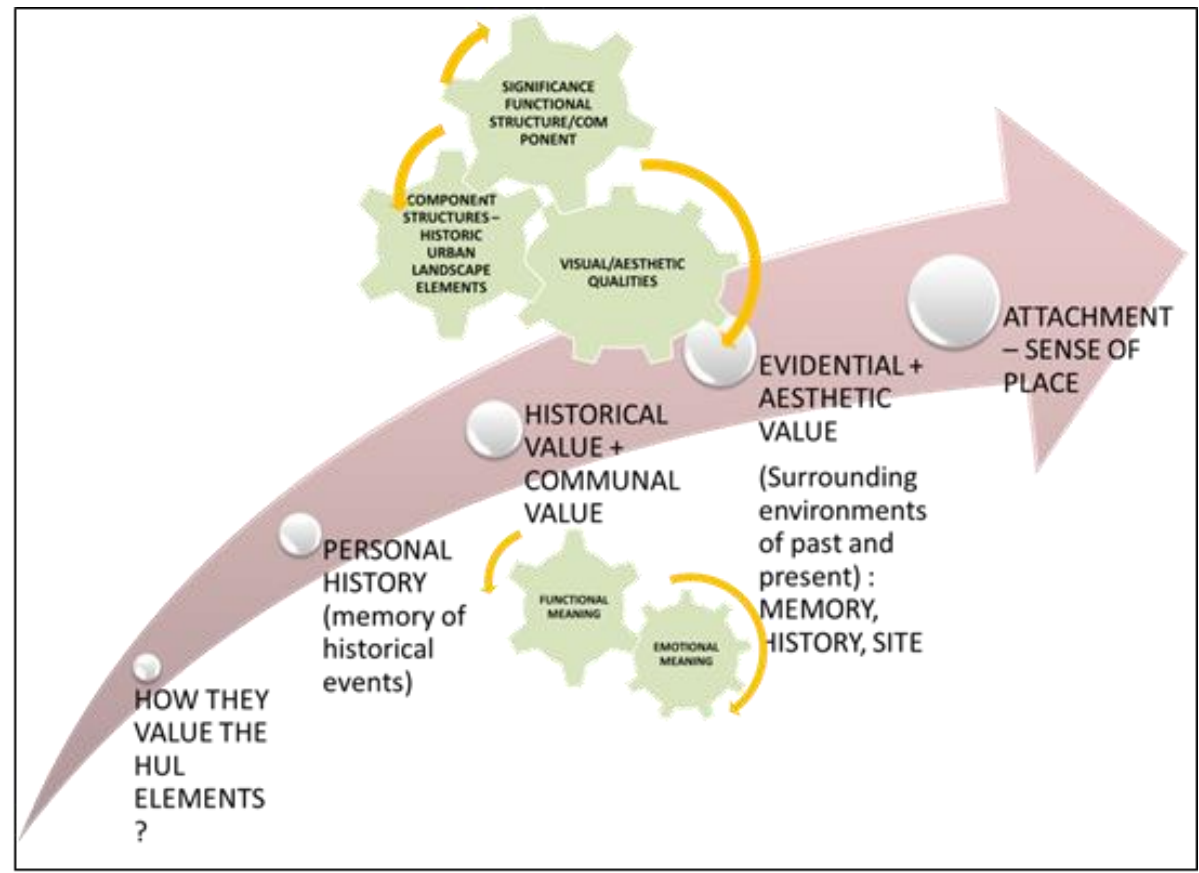

Figure 2: The value of place

Source: Author, 2018

The finding also posits the community associated the place with their childhood memories. It brought in-depth meaning to this city. The people may be comparatively modest, acquiring communal significance through the timeline as a collective memory of stories, which linked to them. They tend to gain value through the resonance of past events in the present, providing reference points for a community's identity or genius loci. They may have fulfilled the community function that has generated in-depth attachment, or shaped some aspect of community behaviour or attitudes. In the end, it will create the character of a place.

This study concurs with previous researchers' statements on the emotional feeling of an individual towards the physical location by defining the meaning of place through person-environment interaction process. In addition, 
this research also agrees with Stephenson's Cultural Value Model that three elements contributed to the value of place, which are: (i) relationship - direct and indirect between the people and its surroundings; (ii) forms - the elements that contribute value to the place; and (iii) practices - the activities occur on place.

The values refer to the qualities of the heritage significance and the expressions towards heritage values of George Town WHS. These lead to the meaning and association of the place. The paper confirms that historic urban landscape (HUL) has its sense of place. According to the various concepts that have been discussed by the previous scholars, this research agrees that the identity or character of the place are the combination of tangible and intangible elements, activities and landscape setting. The people are experiencing and grasping the event and hold the memories of the place. This affective bonding called nostalgia, topophilia or genius loci by previous scholars.

\section{CONCLUSION}

The values emerge as significant elements that shaped the perceptions of the individuals in unique and different ways. It is clear that there is a multiplicity of possible values that heritage may represent for a different person with varies reasons. The findings suggest that tangible elements support the cultural intangible attributes in perceiving the meaning of the place. This research also establishes that the inherited values of the place and its tangible elements only support by the cultural attributes. The city without the people will contribute towards the loss of the character. The memories and the history of the place will be eroded. The character of George Town was symbolized by the personal value of the place. The representation and interpretation of the historic urban landscape elements are shared among the community. As a conclusion, the city that they inherited representing the meaning and attached to their lives' history. The landscape shapes the place by the activities, meaning and its significant historic urban landscape and its setting, which concur with the findings from the previous scholars.

\section{REFERENCES}

Bandarin, F., \& Van Oers, R. (2015). Reconnecting the city: The historic urban landscape approach and the future of urban heritage. Oxford: Willey Blackwell.

Bandarin, F., \& Van Oers, R. (2012). The historic urban landscape: Managing heritage in an urban century. Oxford: Willey Blackwell.

Jokiletho, J. (2007). International charters on urban conservation: Some thoughts on the principles expressed in current international doctrine. City \& Time, 3(3), 23-42.

Jokilehto J. (2006). Considerations on authenticity and integrity in world heritage context. City \& Time, 2(1), 1.

Jokiletho, J. (2005). World heritage: Defining the outstanding universal value. City \& Time, 2. 
Rohayah Che Amat

Inheriting the City: Historic Urban Landscape of George Town Unesco World Heritage Site

Jokiletho, J. (2002, November). Authenticity, integrity and the world heritage convention. World Heritage 2002 Shared Legacy, Common Responsibility Associated Workshops. November 11-12, 2002, Urbino, Pesaro, Italy.

UNESCO. (2011). 36 C/23 Recommendation on the historic urban landscape. Paris: WHC.

UNESCO. (2008). Operational guidelines for the implementation of the World Heritage Convention. Paris: WHC.

Veldpaus, L., Ana, R., \& Bernard, J. F. (2013). Urban heritage: Putting the past into the future. The Historic Environment: Policy \& Practice, 4(1), 18-33. 